\title{
The Prediction of Stiffness of Bamboo-Reinforced Concrete Beams Using Experiment Data and Artificial Neural Networks (ANNs)
}

\author{
Muhtar ${ }^{1, *(0}$, Amri Gunasti ${ }^{1}$, Suhardi $^{2}{ }^{2}$ Nursaid $^{1}$, Irawati ${ }^{1}$, Ilanka Cahya Dewi ${ }^{1}$, \\ Moh. Dasuki ${ }^{1} \mathbb{D}$, Sofia Ariyani ${ }^{1}$, Fitriana ${ }^{1} \mathbb{D}$, Idris Mahmudi ${ }^{1}$, Taufan Abadi ${ }^{1}$, \\ Miftahur Rahman ${ }^{1}{ }^{\mathbb{D}}$, Syarif Hidayatullah ${ }^{1}$, Agung Nilogiri ${ }^{1}$, Senki Desta Galuh ${ }^{1}$, \\ Ari Eko Wardoyo ${ }^{1}$ and Rofi Budi Hamduwibawa ${ }^{1}$ (D) \\ 1 Faculty of Engineering, University of Jember, Jember Indonesia 68121, Indonesia; \\ amrigunasti@unmuhjember.ac.id (A.G.); nursaid@unmuhjember.ac.id (N.); irawati@unmuhjember.ac.id (I.); \\ ilankadewi@unmuhjember.ac.id (I.C.D.); moh.dasuki22@unmuhjember.ac.id (M.D.); \\ sofia.ariyani@unmuhjember.ac.id (S.A.); fitriana@unmuhjember.ac.id (F.); \\ idrismahmudi@unmuhjember.ac.id (I.M.); taufan.abadi@unmuhjember.ac.id (T.A.); \\ miftahurrahman@unmuhjember.ac.id (M.R.); syarifhidayatullah@unmuhjember.ac.id (S.H.); \\ agungnilogiri@unmuhjember.ac.id (A.N.); senki.desta@unmuhjember.ac.id (S.D.G.); \\ arieko@unmuhjember.ac.id (A.E.W.); rofi.hamduwibawa@unmuhjember.ac.id (R.B.H.) \\ 2 Faculty of Agricultural Technology, University of Jember, Jember Indonesia 68121, Indonesia; \\ hardi.ftp@unej.ac.id \\ * Correspondence: muhtar@unmuhjember.ac.id
}

Received: 3 August 2020; Accepted: 19 August 2020; Published: 27 August 2020

Abstract: Stiffness is the main parameter of the beam's resistance to deformation. Based on advanced research, the stiffness of bamboo-reinforced concrete beams (BRC) tends to be lower than the stiffness of steel-reinforced concrete beams (SRC). However, the advantage of bamboo-reinforced concrete beams has enough good ductility according to the fundamental properties of bamboo, which have high tensile strength and high elastic properties. This study aims to predict and validate the stiffness of bamboo-reinforced concrete beams from the experimental results data using artificial neural networks (ANNs). The number of beam test specimens were 25 pieces with a size of $75 \mathrm{~mm} \times 150 \mathrm{~mm} \times 1100 \mathrm{~mm}$. The testing method uses the four-point method with simple support. The results of the analysis showed the similarity between the stiffness of the beam's experimental results with the artificial neural network (ANN) analysis results. The similarity rate of the two analyses is around $99 \%$ and the percentage of errors is not more than $1 \%$, both for bamboo-reinforced concrete beams (BRC) and steel-reinforced concrete beams (SRC).

Keywords: bamboo-reinforced concrete (BRC); stiffness prediction; artificial neural network (ANN)

\section{Introduction}

Some of the advantages of bamboo include having high tensile strength [1], easy to split, cut, elastic fibers, optimal in bearing loads, and it is not a pollutant. At the same time, the weakness of bamboo as a construction material is easily attacked by insects, because the starch content in bamboo is quite high. Therefore, bamboo as a building material requires treatment, such as immersion in water [2,3] and the application of adhesives and waterproof layers [3]. The application of adhesive and waterproof coating has increased the load capacity and stiffness of the BRC beam [4]. Bamboo as a reinforcement of concrete structural elements has been widely used, among other things, as beam reinforcement [2,5-7], bridge frame reinforcement [8], plate or panel reinforcement [9-11], and column reinforcement $[12,13]$. 
The most important mechanical properties of bamboo-reinforced concrete beams are stress, strain, and stiffness. Some previous researchers concluded that bamboo-reinforced concrete beams have lower stiffness compared to steel reinforced concrete beams but have elastic properties and high ductility, so that they are effective in absorbing earthquake energy $[14,15]$. However, low rigidity will lead to reduced construction integrity and excessive structural deformation. The behavior of materials and construction elements, especially the stiffness parameters can be known through the relationship of load and deflection, as shown in Figure 1.

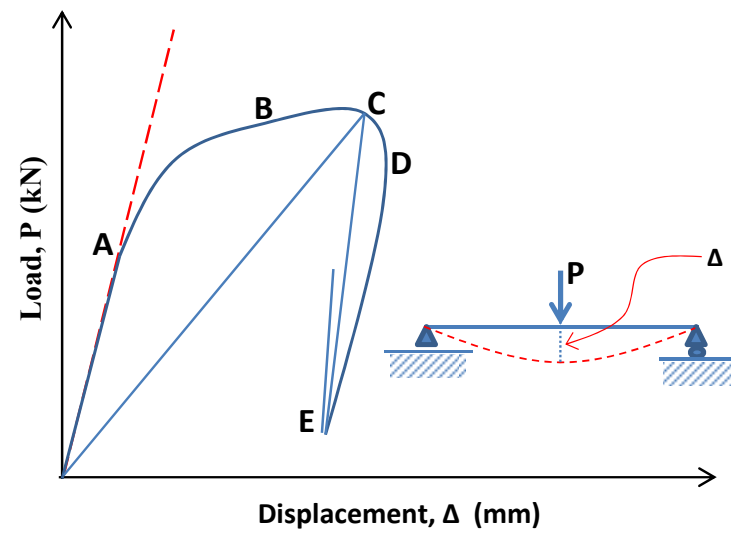

Figure 1. The load vs. deflection relationships of the reinforced concrete beam [15].

The stiffness of bamboo-reinforced concrete beams $(E I)$ is the main factor of structural resistance to the bending deformation of BRC beams. Beam stiffness is a function of the modulus of elasticity of the material $(E)$ and the moment of inertia $(I)$. Moments of inertia before cracking use $I_{g}$, and after cracking they use $I_{c r}$. The effective inertia moment is the value between $I_{g}$ and $I_{c r}$. This understanding can be seen from the behavior of the load vs. deflection relationship in Figure 1. In general, the determination of beam stiffness is based on the results of the beam flexural test, while the calculation of elasticity modulus ( $E$ ) of BRC beams for testing beams with two load points can follow Equations (1) and (2) [15].

$$
\begin{gathered}
E=\frac{23 P L^{3}}{648 \Delta I}\left(\mathrm{~N} / \mathrm{mm}^{2}\right) \\
\Delta=\frac{23 P L^{3}}{648 E I}(\mathrm{~mm})
\end{gathered}
$$

where $E$ is the elasticity modulus, $\Delta$ is the initial crack, $P$ is the initial crack load, $L$ is the span, and $I$ is the inertia moment of the cross-section.

Making conclusions from the results of research on the behavior of bamboo-reinforced concrete beams (BRC) is not easy to take. Correct conclusions must go through data validation and data analysis with other methods, such as statistical analysis, the finite element method [16], or the artificial neural network (ANN) method [17]. The determination of the stiffness of bamboo-reinforced concrete beams (BRC) from the experimental results must be validated by other methods, such as the artificial neural network (ANN) method.

Artificial neural networks (ANNs) consist of many neurons. Neurons are grouped into several layers. Neurons in each layer are connected with neurons in other layers. This does not apply to the input and output layers but only to the layers in between. Information received at the input layer is continued to the layers in ANN one by one until it reaches the output layer. The layer that lies between the input and output is called the hidden layer. However, not all ANNs have a hidden layer; some are only input and output layers.

Artificial neural networks (ANNs) are a powerful tool for solving complex problems in the field of civil engineering. Many researchers have used the ANN method for many structural engineering studies, such as predicting the compressive strength of concrete [18], axial strength of composite 
columns [19], and determination of displacement of concrete reinforcement (RC) buildings [20]. Determination and control of BRC beam stiffness are based on load vs. deflection diagrams. Load data and deflection of experimental results are used as input data and target data in the analysis of artificial neural networks (ANNs).

Some previous researchers have concluded that artificial neural networks (ANNs) can be an alternative in calculating deflection in a reinforced concrete beam. The results of deflection calculations on reinforced concrete using ANN proved to be very effective [21]. ANN is also very well used to predict deflection in the concrete beam with a very strong correlation level of $97.27 \%$ to the test data [22]. Likewise, the use of ANN to predict deflection in cantilever beams produces very accurate outcomes [23]. In this paper, we use uniform load input data, while the target data are the deflection of laboratory test results. Distribution of ANN model data composition consists of $70 \%$ training, $15 \%$ validation, and $15 \%$ testing. The schematic of ANN architecture for rectangular beams is shown in Figure 2.

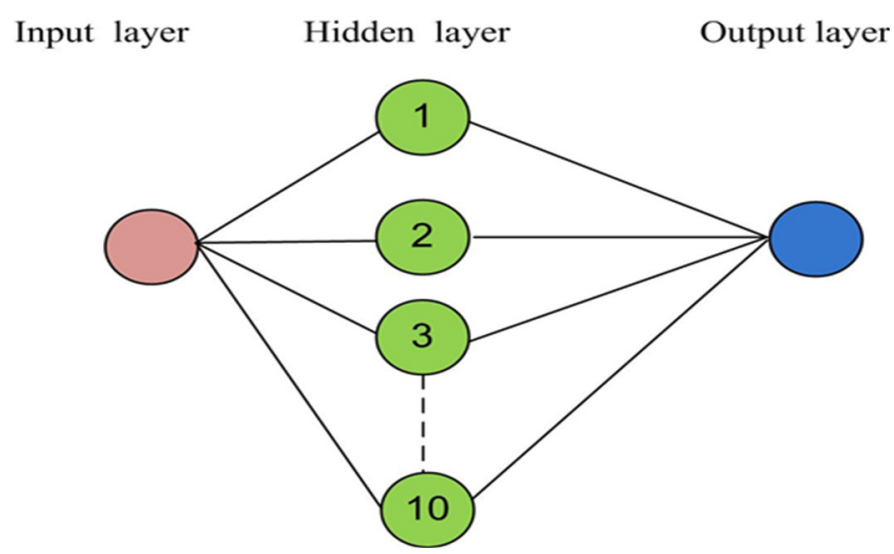

Figure 2. Schematic of ANN architecture for rectangular beams.

The purpose of this study is to validate the behavior and stiffness of the BRC beam experimental results with the artificial neural network (ANN) method. Errors resulting from experimental data are usually caused by some things, such as human errors, calibration of tools that have expired, test method errors, and test items that do not match. Therefore, the experimental data are evaluated and compared with the results of the artificial neural network (ANN) method. In this study, the experimental data are thought to have a large deviation from the results of the artificial neural network (ANN) method. Then, an efficient ANN-based computational technique is presented to estimate the load vs. deflection of bamboo-reinforced concrete blocks (BRC). Furthermore, stiffness observations are made at the same loading point.

\section{Materials and Methods}

Experimental data were obtained from a single reinforced BRC beam bending test with two load points based on ASTM C 78-02 [24]. The size of bamboo reinforcement is $15 \mathrm{~mm} \times 15 \mathrm{~mm}$, which is treated first through immersion, drying, and the waterproof coating using Sikadur ${ }^{\circledR}-752$ [3]. As a strengthening of bamboo reinforcement used diameter hose-clamps $\frac{3}{4}$ " [8]. The number of beam test specimens were 25 pieces with a size of $75 \mathrm{~mm} \times 150 \mathrm{~mm} \times 1100 \mathrm{~mm}$ consisting of 24 BRC beams and 1 SRC beam with steel reinforcement. The detailed image of the BRC beam specimen is shown in Figure 3. The design of the concrete mixture in this study was Portland Pozzolana Cement (PPC), sand, coarse aggregate, and water with a proportion of 1:1.81:2.82:0.52. The average compressive strength of concrete at the age of 28 days is $31.31 \mathrm{MPa}$. The steel used is plain steel with $f_{y}=240 \mathrm{MPa}$. 


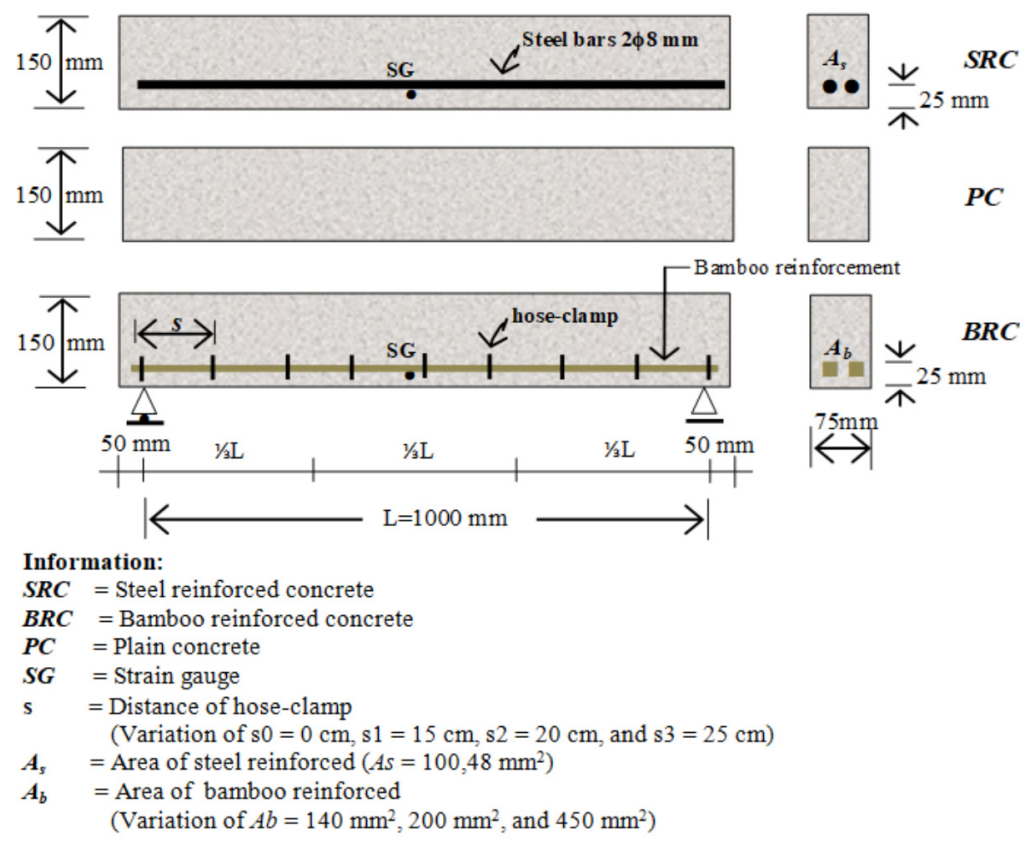

Figure 3. Geometry and details of bamboo-reinforced concrete beams.

The beam flexural test is carried out on two simple supports, namely joint support and roller support. Load in the form of a centralized load divided into two load points with a distance of $1 / 3 \mathrm{~L}$ from the support. The strain gauge is mounted on the bamboo reinforcement with a distance of $\frac{1}{2} \mathrm{~L}$ from the support to determine the strain that is occurring. To detect deflection, a linear variable differential transformer is installed at a distance of $\frac{1}{2} \mathrm{~L}$ from the support. To get the stages of loading from zero until the beam collapses, a hydraulic jack and load cell are used that are connected to the load indicator. Loading is carried out slowly at a speed of $8 \mathrm{~kg} / \mathrm{cm}^{2}-10 \mathrm{~kg} / \mathrm{cm}^{2}$. Load reading on the load indicator is used to control the hydraulic jack pump, deflection, and strain according to the planned loading stage. However, when the test specimen reaches the ultimate load, deflection readings become the control of readings of the strain and load. Hydraulic jack pumping continues to take place slowly according to the deflection reader command. The collapse pattern is observed and identified through cracks that occur, starting from the first crack until the beam collapses. The BRC beam test setting is shown in Figure 4.

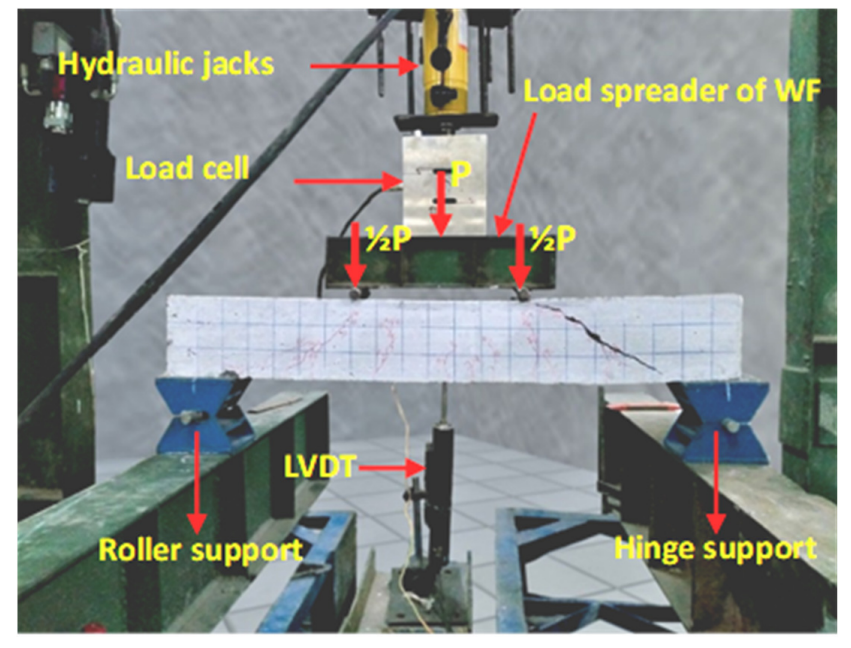

Figure 4. Test arrangement of bamboo-reinforced concrete beams. 


\section{Results}

Mechanical properties and stress-strain characteristics of steel and bamboo materials are the dominant factors that influence the shape of the load vs. deflection relationship behavior models. The difference in the stress and strain relationship pattern of steel and bamboo is seen in the difference in melting point and fracture stress, as shown in Figures 5 and 6. Steel reinforcement shows a clear melting point, whereas bamboo reinforcement does not show a clear melting point. Both of them show a clear stress fracture point, but in bamboo reinforcement, after fracture stress occurs, the strain-stress relationship pattern tends to return to zero, as shown in Figure 5. This shows that bamboo has good elastic properties.

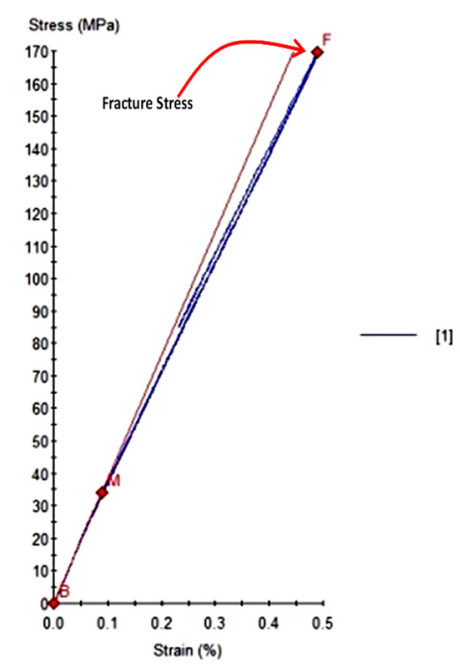

Figure 5. The stress-strain relationship of normal bamboo reinforcement.

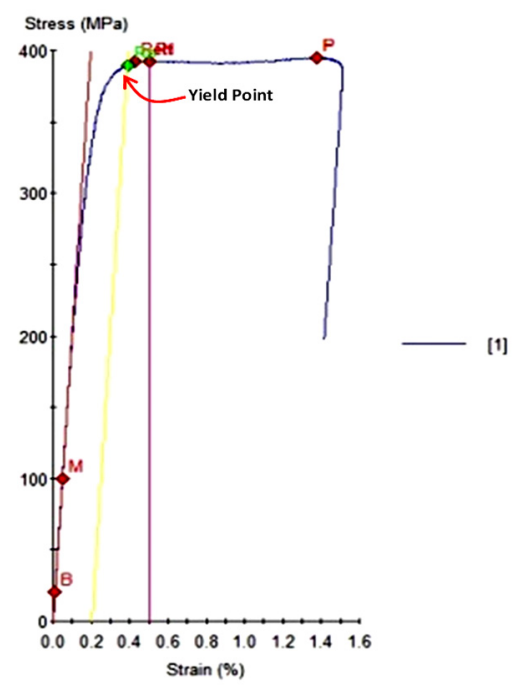

Figure 6. The stress-strain relationship of steel reinforcement.

Figure 7 shows the relation between load vs. deflection of the BRC beam and SRC beam from the analysis of experimental data, while Figure 8 shows the relationship between load vs. deflection of BRC beams and SRC beams resulting from the analysis of artificial neural network (ANN) methods. The BRC beam tends to have a large deflection, but when the maximum load is reached, the deflection tends to return to zero if the load is released, as shown in Figure 9. Documentation of the gradual load discharge after the ultimate load has been reached can be seen in the following link: https://goo.gl/6AVWmP [14] and the BRC beam flat back. This shows its compatibility with bamboo strain-stress behavior. The load 
vs. deflection relationship of the SRC beam shows the existence of an elastic limit, elasto-plastic limit, and plastic, as shown in Figure 7. While the relationship of load vs. deflection of the BRC beam shows a linear line until the maximum load limit and after the peak load, the deflection returns to zero, as shown in Figure 9.

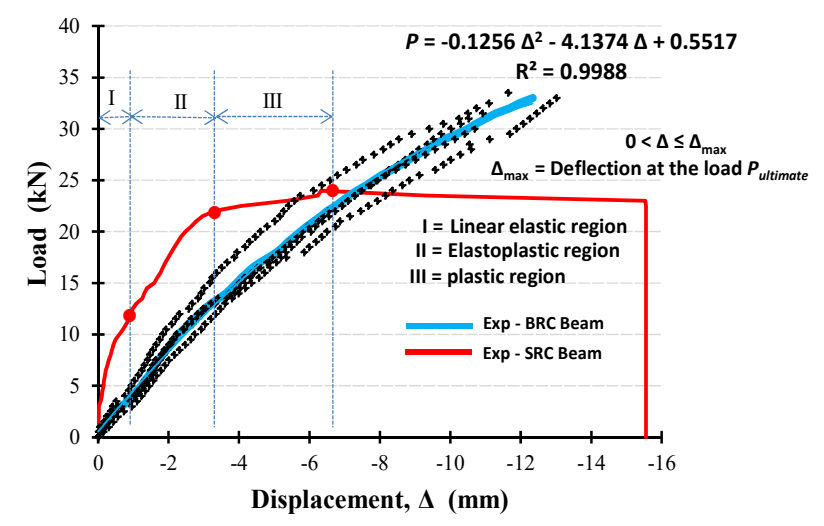

Figure 7. The load vs. deflection relationship of the BRC beam from experiment [14].

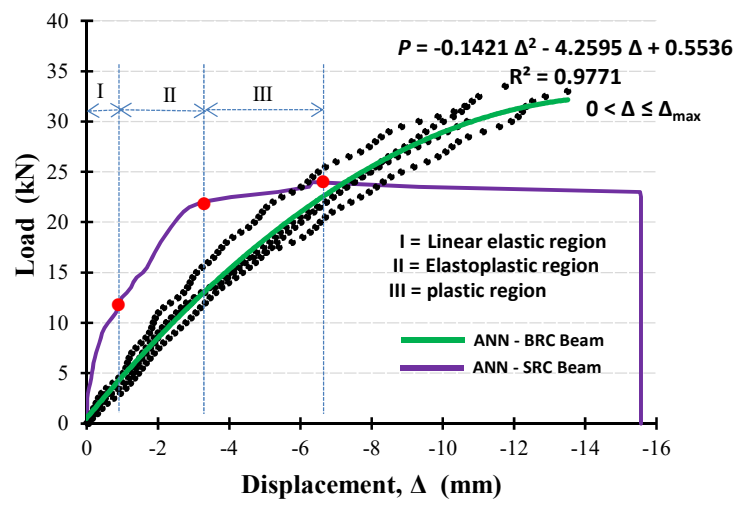

Figure 8. The load vs. deflection relationship of the BRC beam from the ANN method.

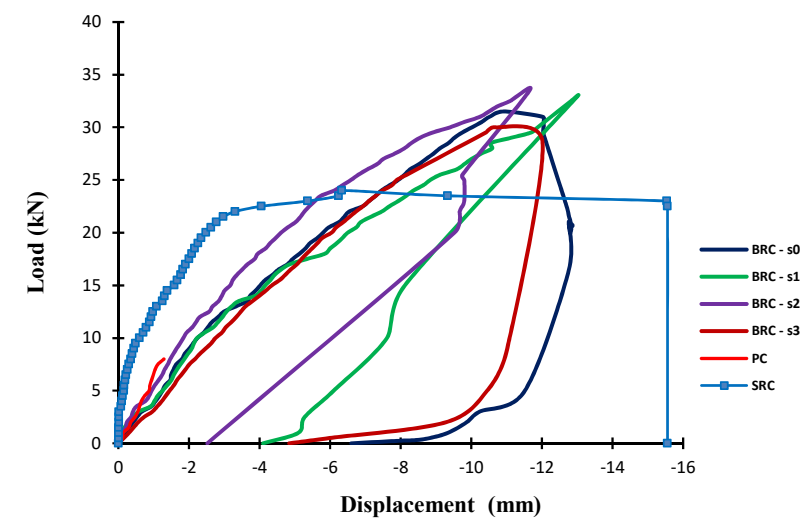

Figure 9. The load vs. deflection relationship of the BRC beam and the SRC beam until the gradual release of the load.

In this case, the ANN studies the network to diagnose the shape and distribution of data from the deflection of BRC beams and SRC beams with different loads. After reaching small and acceptable variations of errors, training in neural networks is stopped. Then, the neural network model is tested, and the results are validated by comparing it with the results of the analysis of experimental data. Every network created in the ANN is trained, tested, and validated for all data samples to identify the best technique. The data input for the network used is the deflection data from the experimental 
results of the BRC beam and the SRC beam. The deflection data file of the experimental results is saved in the form of MS Excel. Data are distributed into training (70\%), testing (15\%), and validation (15\%).

Figures 10-13 show the prediction of the load vs. deflection relationship of the BRC beam and Figure 14 shows the prediction of the relationship of load vs. deflection of the SRC beam from the ANN method analysis. The correlation value of laboratory data by using ANN shows an average value of R Square of 0.999 . The results of predictions by the ANN method show that the percentage of errors is very small, with a maximum error of $0.26 \%$. Overall, the comparison of experimental data with the results of the ANN method predictions shows no more than a 1\% error. From the data results of the two analyses and the pattern of load vs. deflection relationships, it can be concluded that the stiffness of the BRC beams is similar. Then, the stiffness prediction with the elasticity modulus parameter can be calculated based on the load vs. deflection relationship graph, as shown in Figure 15.
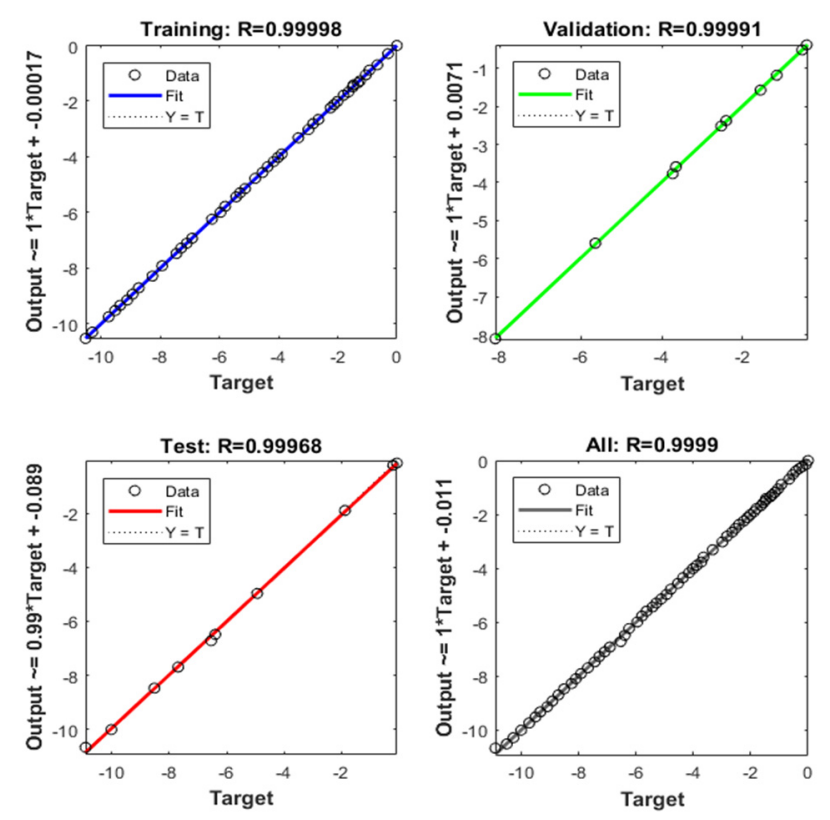

Figure 10. The correlation value of laboratory data and the ANN method (BRC-1 beam).
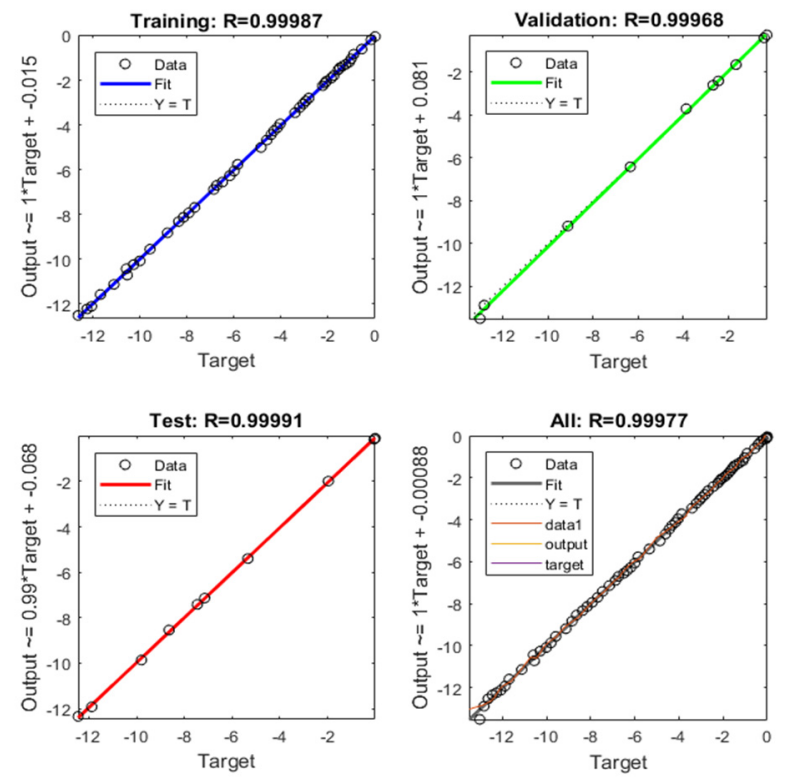

Figure 11. The correlation value of laboratory data and the ANN method (BRC-2 beam). 

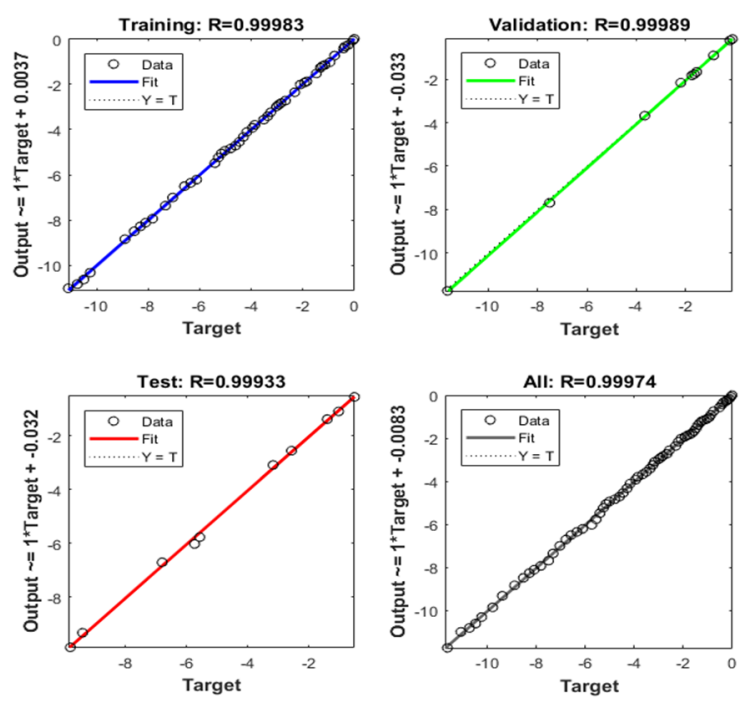

Figure 12. The correlation value of laboratory data and the ANN method (BRC-3 beam).
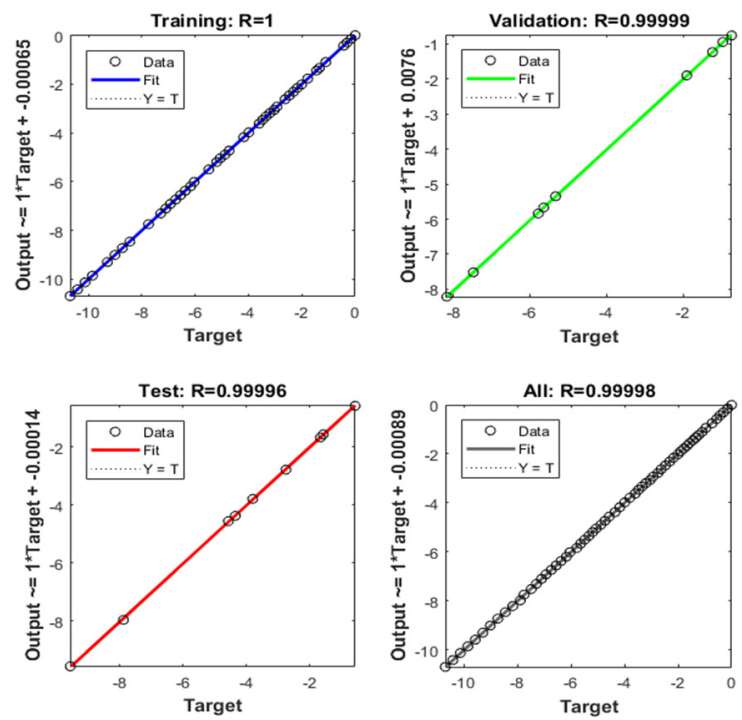

Figure 13. The correlation value of laboratory data and the ANN method (BRC-4 beam).
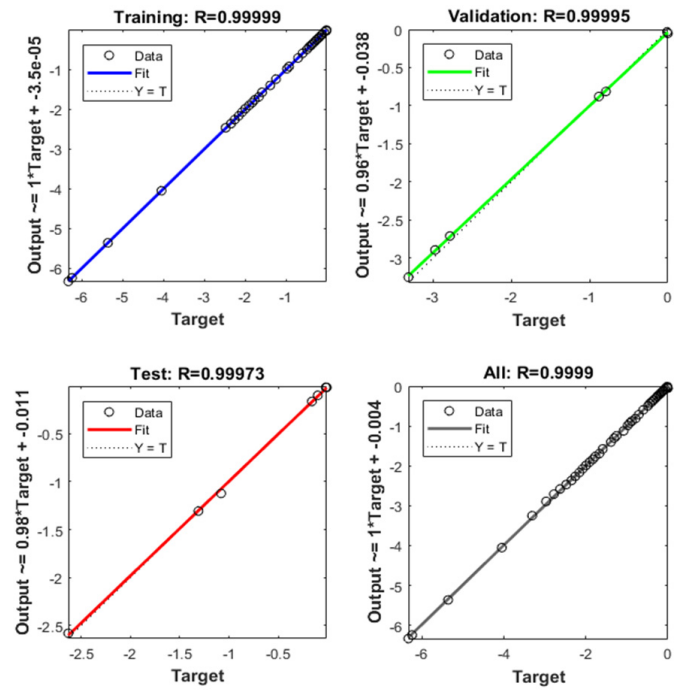

Figure 14. The correlation value of laboratory data and the ANN method (SRC beam). 


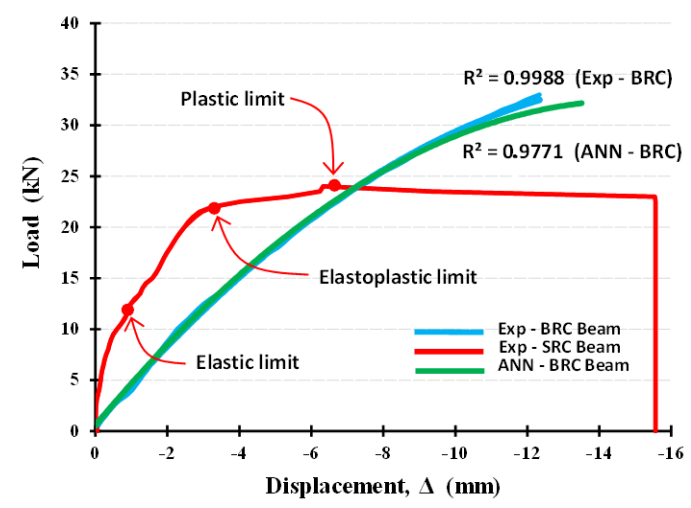

Figure 15. The load vs. deflection relationship the experimental results and ANN analysis.

Figure 15 shows the combined relationship of the load vs. deflection beam of the experimental BRC beam and the ANN analysis results. Figure 15 shows a graph that is coincidental with an error rate of not more than $1 \%$, so that the combined graph of the load vs. deflection relationship can be used to determine the modulus of elasticity or the stiffness of the BRC beam.

\section{Discussion}

Figure 16 shows the results of the two methods of data analysis being a load vs. deflection pattern. From this load vs. deflection pattern, the stiffness of bamboo-reinforced concrete beams can be predicted. Prediction of stiffness with the elasticity modulus parameters can be calculated based on the load vs. deflection relationship graph. The graph of load vs. deflection relationship shows that at $40 \%$ ultimate load, the stiffness of the BRC beam has a stiffness lower to $44 \%$ than the SRC beam. Meanwhile, if viewed from the graph load vs. deflection relationship, ANN analysis results with experimental results show the same stiffness value up to $80 \%$ ultimate load. The stiffness of BRC beams at loads above $80 \%$ indicates a difference, namely the stiffness of the ANN analysis results is lower than the experimental results, as shown in Figure 16.

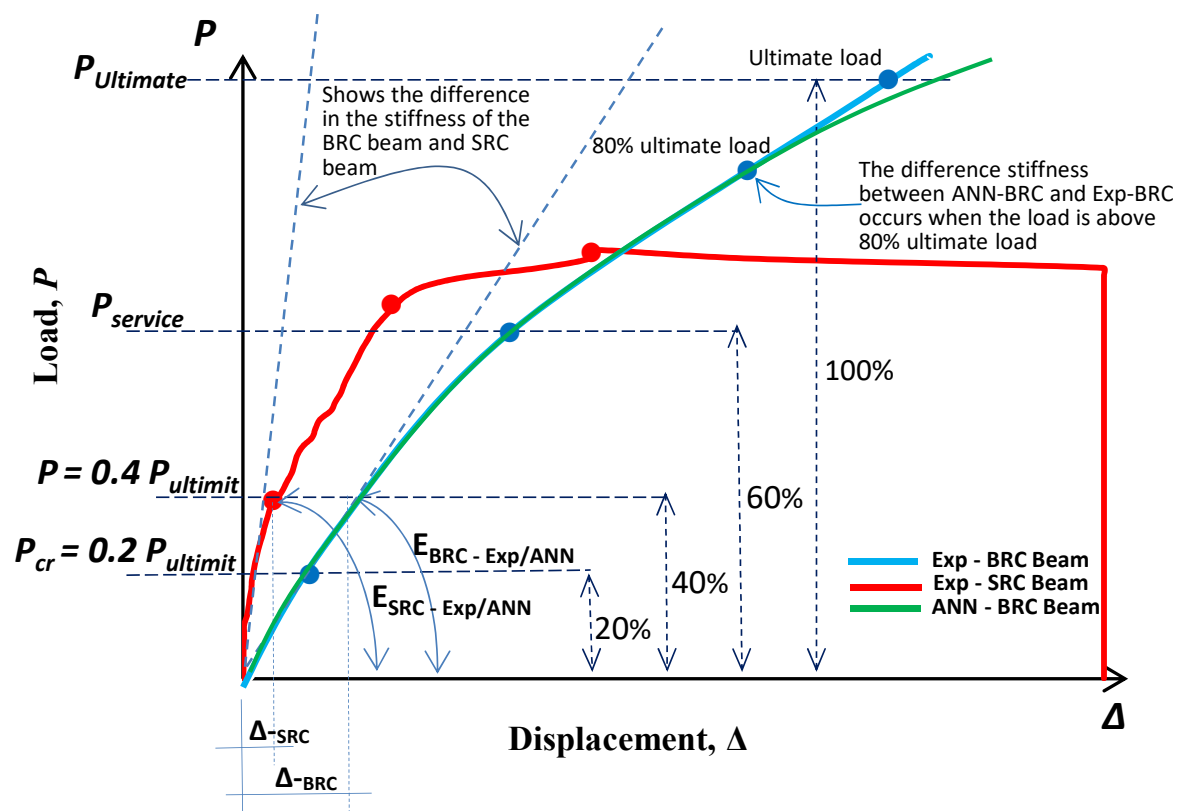

Figure 16. The difference in stiffness between the SRC beam, BRC beam, and BRC beam of ANN analysis result. 
Table 1 shows that the initial crack (elastic region) of the BRC beam is in the range of $20 \%$ of the ultimate load and $40 \%$ of the ultimate load for the SRC beam. Whereas the effect of installing hose-clamps on bamboo reinforcement on the ultimate load of BRC beams is optimum at a distance of $20 \mathrm{~cm}$ (BRC-s2) and decreases at a distance of $25 \mathrm{~cm}$, this indicates that installing hose-clamps that are too tight will reduce the elastic properties of bamboo reinforcement and decrease its ductility, as shown in Figure 17. Installation of hoses that are too tight does not increase the stiffness of the BRC beam but instead reduces the load capacity. The control of the load vs. deflection relationship with the ANN method is taken from the results of the regression analysis of six beam samples in each group, namely the BRC-s0, BRC-s1, BRC-s2, and BRC-s3 groups, plus one SRC beam, as shown in Figures 7 and 8. The ANN analysis results for each group are regressed back and used as the final result to determine the stiffness of the BRC beam, as shown in Figure 15. The ANN analysis results for each group are shown in Figures 10-13.

Table 1. The value of the average initial crack loads and ultimate loads based on theoretical calculations and experimental.

\begin{tabular}{cccccc}
\hline \multirow{2}{*}{ Specimens } & \multicolumn{2}{c}{ Theoretical Calculations } & \multicolumn{3}{c}{ Flexural Test Results } \\
\cline { 2 - 6 } & $\begin{array}{c}\text { First Crack } \\
\text { Load (kN) }\end{array}$ & $\begin{array}{c}\text { Ultimate } \\
\text { Load (kN) }\end{array}$ & $\begin{array}{c}\text { Average First } \\
\text { Crack Load (kN) }\end{array}$ & $\begin{array}{c}\text { Average Failure } \\
\text { Load (kN) }\end{array}$ & $\begin{array}{c}\text { Average Deflection at } \\
\text { Failure (mm) }\end{array}$ \\
\hline (a) BRC-s0 & 6.87 & 32.19 & 8.25 & 30.25 & 11.41 \\
(b) BRC-s1 & 6.87 & 32.19 & 7.25 & 32.00 & 12.60 \\
(c) BRC-s2 & 6.87 & 32.19 & 8.00 & 33.25 & 12.01 \\
(d) BRC-s3 & 6.87 & 32.19 & 7.50 & 29.75 & 9.15 \\
(e) SRC & 6.51 & 16.14 & 10.00 & 24.00 & 6.33 \\
\hline
\end{tabular}

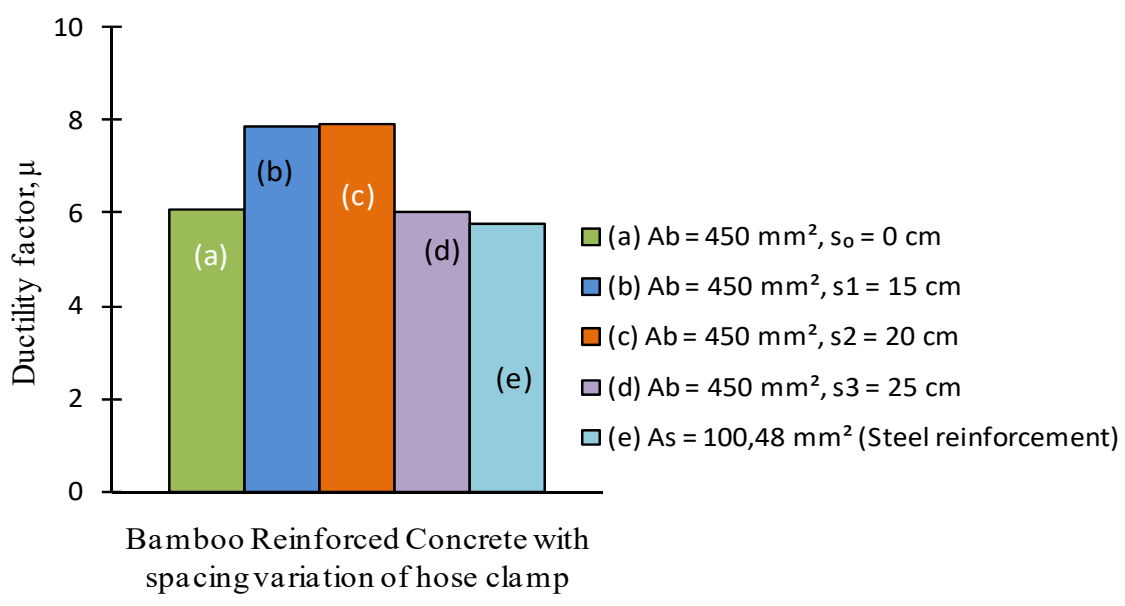

Figure 17. The effect of hose-clamp distance on the ductility value.

Stiffness $(E I)$ is the main parameter of the resistance of structural elements to bending deformation. The basic properties and behavior of stress-strain material are the dominant factors determining the size of the rigidity of structural elements. SRC beam stiffness has a greater stiffness than the BRC beam stiffness. This is due to the steel reinforcement having an elasticity modulus greater than the elasticity modulus of bamboo. However, the BRC beam has good elastic properties, in harmony with the pattern of stress-strain relationships of bamboo. This proves that bamboo material has good earthquake energy absorption. The behavior of elastic on the BRC beam can be seen in the video at the following link: https://goo.gl/6AVWmP [14].

Integrity and rigidity in a structure are essential. Therefore, the low stiffness of the BRC beam is essential to find a solution. Solutions to solve the low stiffness of the BRC beam, such as the graph diagram in Figure 16, can be done in two ways, namely giving strength to bamboo reinforcement and applying the principle of confined concrete [7]. Strengthening of bamboo reinforcement can be achieved by using adhesive, increasing surface roughness, installing hose-clamps that function as 
hooks and shear connectors, and so on. An equally important solution is to increase the strength of the concrete to support increasing the stiffness of the BRC beam. Previous studies showed that the cause of the majority of BRC beam collapse is by slippage [14] and shear collapse [14]. The principle of confined concrete is fundamental to do by giving shear reinforcement to the BRC beam.

\section{Conclusions}

Predictions of bamboo-reinforced concrete beam stiffness based on experimental results and analysis results of artificial neural network (ANN) methods show very close similarities or with an error prediction of no more than $1 \%$.

Bamboo-reinforced concrete (BRC) beams have a lower stiffness of up to $40 \%$ when compared to steel reinforced concrete (SRC) beams.

The stiffness of the BRC beam of experimental result and the artificial neural network (ANN) analysis results have in common up to $80 \%$ of the ultimate load and, afterward, show differences.

The coatings of adhesives, modification of bamboo reinforcement roughness, and the use of shear reinforcement are solutions to increase the stiffness and capacity of the BRC beam.

Installation of a hose-clamp that is too tight does not increase the stiffness of the BRC beam but reduces its elastic properties and reduces its load capacity.

Author Contributions: Conceptualization, M., S., and A.G.; methodology, M., S., and A.N.; software, S., S.A., A.N., and A.E.W.; validation, M., I., and I.C.D.; formal analysis, M., S., and M.D.; investigation, N., and T.A.; resources, N.; data curation, M., and S.; writing-original draft preparation, A.N. and F.; writing-review and editing, M. and S.D.G.; visualization, M.R. and S.H.; supervision, N.; project administration, R.B.H.; funding acquisition, N. and I.M. All authors have read and agreed to the published version of the manuscript.

Funding: APC was financed entirely by the DPRM Republic of Indonesia and LPPM of the University of Muhammadiyah, Jember, Indonesia.

Acknowledgments: Funding Research is fully borne by the research Program, Directorate of Research and Community Service, Directorate General of Research and Technology Strengthening and Development of the Ministry of Research, Technology, and Higher Education of the Republic of Indonesia.

Conflicts of Interest: The authors declare no conflict of interest.

\section{References}

1. Ghavami, K. Bamboo as reinforcement in structural concrete elements. Cem. Concr. Compos. 2005, 27, 637-649. [CrossRef]

2. Agarwal, A.; Nanda, B.; Maity, D. Experimental investigation on chemically treated bamboo reinforced concrete beams and columns. Constr. Build. Mater. 2014, 71, 610-617. [CrossRef]

3. Muhtar, M. Experimental data from strengthening bamboo reinforcement using adhesives and hose-clamps. Data Brief 2019, 27, 104827. [CrossRef] [PubMed]

4. Muhtar, M. Cracked Pattern of Bamboo Reinforced Concrete Beams Using Double Reinforcement with the Strengthening on Tensile Reinforcement. Int. J. Eng. Res. Technol. 2020, 13, 608-612.

5. Rahman, M.M.; Rashid, M.H.; Hossain, M.A.; Hasan, M.T.; Hasan, M.K. Performance evaluation of bamboo reinforced concrete beam. Int. J. Eng. Res. Technol. IJET-IJENS 2011, 11, 113-118.

6. Dewi, S.M.; Nuralinah, D.; Munawir, A.; Wijaya, M.N. Crack behavior study of bamboo reinforced concrete beam with additional pegs in reinforcing. Int. J. Civ. Eng. Technol. 2018, 9, 1632-1640.

7. Dewi, S.M. The flexural behavior model of bamboo reinforced concrete beams using a hose clamp. Proc. Mater. Sci. Eng. Chem. 2019, 276, 1033.

8. Muhtar, A.; Gunasti Manggala, A.S.; Nusant, A.F.P.; Hanafi, A.N. Effect of reinforcement details on precast bridge frames of bamboo reinforced concrete to load capacity and crack patterns. Int. J. Eng. Res. Technol. 2020, 13, 631-636.

9. Puri, V.; Chakrabortty, P.; Anand, S.; Majumdar, S. Bamboo reinforced prefabricated wall panels for low-cost housing. J. Build. Eng. 2017, 9, 52-59. [CrossRef]

10. Maruthupandian, G.; Saravanan, R.; S Suresh, K.S.; Sivakumar, B.G. A Study on Bamboo Reinforced Concrete Slabs. J. Chem. Pharm. Sci. A 2016, 9, 978-980. 
11. Daud, N.M.; Nor, N.M.; Yusof, M.A.; Yahya, M.A.; Munikanan, V. Axial and flexural load test on untreated bamboocrete multi-purpose panel. Int. J. Integr. Eng. 2018, 10, 28-31.

12. Tripura, D.D.; Singh, K.D. Mechanical behavior of rammed earth column: A comparison between unreinforced, steel and bamboo reinforced columns. Mater. Constr. 2018, 68, 174. [CrossRef]

13. Rameshwar, S.; Kale, A.; Rashmirana, P. Suitability of Bamboo as Reinforcement in Column. Int. J. Recent Innov. Trends Comput. Commun. 2016, 4, 270-272.

14. Dewi, S.M. Enhancing bamboo reinforcement using a hose-clamp to increase bond-stress and slip resistance. J. Build. Eng. 2019, 26, 100896.

15. Dewi, S.M. The Stiffness and Cracked Pattern of Bamboo Reinforced Concrete Beams Using a Hose Clamp. Int. J. Civ. Eng. Technol. 2018, 9, 273-284.

16. Muhtar, M. Numerical validation data of tensile stress zones and crack zones in bamboo reinforced concrete beams using the Fortran PowerStation 4.0 program. Data Brief 2020, 29, 105332. [CrossRef]

17. Suryanita, R.; Maizir, H.; Jingga, H. Prediction of Structural Response due to Earthquake Load using Artificial Prediction of Structural Response due to Earthquake Load using Artificial Neural Networks. In Proceedings of the International Conference on Engineering \& Technology, Computer, Basic \& Applied Sciences, Bangkok, Thailand, 20-21 June 2016.

18. Naderpour, H.; Kheyroddin, A.; Amiri, G.G. Prediction of FRP-confined compressive strength of concrete using artificial neural networks. Compos. Struct. 2010, 92, 2817-2829. [CrossRef]

19. Ahmadi, M.; Naderpour, H.; Kheyroddin, A. Utilization of artificial neural networks to prediction of the capacity of CCFT short columns subject to short term axial load. Arch. Civ. Mech. Eng. 2014, 14, 510-517. [CrossRef]

20. Khademi, F.; Akbari, M.; Nikoo, M. Displacement determination of concrete reinforcement building using data-driven models. Int. J. Sustain. Built Environ. 2017, 6, 400-411. [CrossRef]

21. Kaczmarek, M.; Szymanska, A. application of artificial neural networks to predict the deflections of reinforced concrete beams. Stud. Geotech. Mech. 2016, 38, 37-46. [CrossRef]

22. Abd, A.M.; Salman, W.D.; Ahmed, Q.W. Ann and statistical modelling to predict the deflection of continuous reinforced concrete. Diyala J. Eng. Sci. 2015, 134-143.

23. Ya, T.T.; Alebrahim, R.; Fitri, N.; Alebrahim, M. Analysis of Cantilever Beam Deflection under Uniformly Distributed Load using Artificial Neural Networks. MATEC Web Conf. 2019, 4, 06004.

24. ASTM C78/C78M-02. Standard Test Method for Flexural Strength of Concrete (Using Simple Beam with Third-Point Loading); ASTM International: Sikangshihoken, PA, USA, 2002. 